\title{
In the Pursuit of Green in COVID-19: Harnessing the Existing Talent to Pursue Green Corporate Entrepreneurship
}

\author{
Essa Khan ${ }^{1 *}$, Muhammad Shujaat Mubarik ${ }^{2}$ and Zubair Ali Shahid ${ }^{1}$ \\ ${ }^{1}$ Faculty of Business Administration and Social Sciences, Mohammad Ali Jinnah University, Karachi, Pakistan, ${ }^{2}$ Institute of \\ Business Management, College of Business Management, Karachi, Pakistan
}

\section{OPEN ACCESS}

Edited by:

Naeem Akhtar,

University of Engineering and

Technology, Pakistan

Reviewed by:

Vikas Arya,

International University of

Rabat, Morocco

Cristina García-Ael,

National University of Distance

Education (UNED), Spain

${ }^{*}$ Correspondence:

Essa Khan

essakhan76@gmail.com

Specialty section:

This article was submitted to

Organizational Psychology,

a section of the journal

Frontiers in Psychology

Received: 02 August 2021 Accepted: 27 September 2021

Published: 25 October 2021

Citation:

Khan E, Mubarik MS and Shahid ZA

(2021) In the Pursuit of Green in COVID-19: Harnessing the Existing Talent to Pursue Green Corporate Entrepreneurship.

Front. Psychol. 12:751961. doi: 10.3389/fpsyg.2021.751961
The study was conducted to ascertain the role of talent management practices in promoting green corporate entrepreneurship through the median of organizational engagement in the context of COVID-19. The study is quantitative and deductive in nature. The data was collected from 323 employees working in the large manufacturing industry. The data was collected through a self-administered survey and the data analysis was done through Smart-PLS, both measurement and structural models were evaluated. The study found that talent management is related to green corporate entrepreneurship. The study also confirmed the mediating role of organizational engagement relating talent management with green corporate entrepreneurship. This study will develop insight for the corporate managers and decision-makers to understand the intricacies of the talent management process and its interplay with green corporate entrepreneurship, and organizational engagement. Talent Management is concerned with the process of hiring, developing, and retaining highly competent incumbents for pivotal positions. Hence, the role of the talent management process invariably affects the organizational processes and outcomes like creativity and innovation, which come under the umbrella of corporate entrepreneurship. This study will not only add value in empirical research of the chosen concepts and constructs, but it will also bridge the theoretical gap between talent management and corporate entrepreneurship. It is the first study that related talent management practices to green corporate entrepreneurship. Furthermore, it is the first study that examined the mediating role of organizational engagement relating talent management to green corporate entrepreneurship.

Keywords: talent management, green corporate entrepreneurship, organizational engagement, COVID-19, entrepreneurship

\section{INTRODUCTION}

Increased competition coupled with heightened environmental concerns has changed the dynamics of business. Firms, to survive and grow, are inexorably required to be competitive and environmentally friendly (Martinez-Martinez et al., 2019; Khan et al., 2021b). To achieve these complementing ends of competitiveness and environmental friendliness, firms, in future, need to have new ventures that along with being economically feasible are also required to be 
environmentally friendly. The need for environmental friendliness is further augmented with the rise of current pandemic known as COVID-19. COVID-19 has compelled the organizations to have an increased concern for employees along with being environmentally sustainable. The need for employee focus is augmented because of the pandemic caused job related uncertainty. Moreover, being environmental friendly is also a solution to COVID (Abubakar, 2020; Dwivedi et al., 2020; Maritz et al., 2020). The existing concept of corporate entrepreneurship, defined as activities aimed at creating new businesses in the established companies (Vanacker et al., 2017), addresses the competitiveness of the firm, but does not address the environmental concerns. Such a strategy, despite its sound track (Kuratko, 2017), does not bode well with the more environmentally aware and active customers. So, the way forward is sustainable or green corporate entrepreneurship, the genre of corporate entrepreneurship fusing the innovativeness of corporate entrepreneurship with the idea of sustainability (Miles et al., 2009). Sustainable corporate entrepreneurship along with the traditional innovation in business model, includes; responsible environmental management, social accountability and economic performance (Miles et al., 2009).

The predecessor of green corporate entrepreneurship has been studied for its possible determinants, linking mechanisms and boundary conditions. The search for the determinants resulted in the following list; knowledge management (Guadamillas et al., 2008), human resource practices (Hayton, 2005; Kühn et al., 2016), high-performance human resource practices (Zhang et al., 2008; Shehata et al., 2020). Additionally, the academicians, exploring the linking mechanism relating corporate entrepreneurship relating to different determinants, found organizational citizenship behavior (Zhang et al., 2008), knowledge behavior (Mustafa et al., 2013) and absorptive capacity (Shafique and Kalyar, 2018). On the other hand, the understanding of sustainable corporate entrepreneurship is at nascent stage. A study conducted in South Africa found organization's environmental concern to be related to environmentally responsible intrapreneurship (Christos, 2017). Despite being the only way forward, the absence of scholarly work on green corporate entrepreneurship is an encouraging sign. The current study is being undertaken to fill the existing void.

The strong ripples and undercurrents created by the hyper-competitive world spares no one (Khan et al., 2020). Business giants like Blackberry, Kodak, and Panasonic were once household names, are now unknown entities for the new generation. Despite the severe competition, some firms have maintained their existence to this day. Apple and Google are the two names that have successfully managed to ward off the annihilating prowess of competition (Denning, 2021). It raises the question as to what differentiates between the firms that survive and grow in the face of the ever-changing world caused by newly emerging ideas (Sharon, 2020). The answer to this moot is the ability of the firms to search and use the emerging opportunities (Jiang et al., 2021). The effectiveness of corporate entrepreneurship in improving the firm performance has catapulted an increased interest by the researchers. Different ways are being evaluated for their usefulness in affecting corporate entrepreneurship.

The role of human resource management is pivotal in motivating the employees to indulge in extra-role behavior (BosNehles and Veenendaal, 2019). In the same vein, HR practices can be attributed to green corporate entrepreneurship (Gardas et al., 2019). One of the main components of sustainable HRM is to manage the talent (Ehnert, 2011). Talent management; the acquiring talent, developing and retaining talent (Collings et al., 2019), is being studied for its role to instigate green corporate entrepreneurship. In the preceding lines, an attempt is being made to explicate how talent management practices can be instrumental in harnessing the creative potential of employees to indulge in green corporate entrepreneurship. Two reasons are being forwarded for the appropriateness of talent management to affect green corporate entrepreneurship. First, talent management practices groom the employees to have a broad perspective along with positive work attitude and organizational congruence (Mensah, 2015; Mensah, 2019). With the augmented resourcefulness and improved understanding, employees work for sustaining the organization along with sustaining the environment as talent management is found to be related to innovation (Salau et al., 2018; van den Broek et al., 2018) and sustainable work behavior (Mujtaba and Mubarik, 2021). In light of this evidence, a positive relationship between talent management practices and green corporate entrepreneurship is proposed. Second, the employee centered practices of talent management practices provide the employees with the impetus to reciprocate in the same coin. Using the basic tent of social exchange theory (Blau, 1964), we propose that employee centric organizational practices will invoke similar behavior among the employees. Green corporate entrepreneurship is one such pro-organizational behavior expected from the employees. In this study, an attempt is being made to ascertain the role of talent management to increase green corporate entrepreneurship. Second, the study is seeking to unfurl the mediating role of organizational engagement linking talent management practices with green corporate entrepreneurship.

\section{LITERATURE REVIEW}

\section{Sustainable Corporate Entrepreneurship}

Corporate entrepreneurship is one of the critical strategic approaches in this globally competitive economy. Corporate entrepreneurship is also found to work as a change agent for the community (Martín-Rojas et al., 2020). In recent times organizations are highly motivated to become more entrepreneurial in their practices and approaches (Peschl et al., 2020; Shehata et al., 2020). Creativity and Innovation are mostly dependent on entrepreneurial activities and individual mindsets. Employees with talent are considered to be a source of ideas, intellect, and innovation (Sadat and Nasrat, 2020). The fruition of corporate entrepreneurship is linked with the presence and use of talented individuals who are capable of generating new ideas and going to the process of creativity and innovation (Kabir, 2019). To some researchers corporate entrepreneurship to be a 
booster for firm profitability and economic development (Mayer and Motoyama, 2020; Si et al., 2020).

The rising concern for environment has evolved the business thinking. Instead of parochially concentrating on entrepreneurial performance, the firms, realizing the importance of environment, have begun to incorporate sustainability in their ideas. The ensuing sustainable corporate entrepreneurship is the embodiment of businesses that value both sustainability and corporate entrepreneurship (Provasnek et al., 2017). The slack at either bleeds the firm differently. The firm, being sustainable but not entrepreneurial, will not be economically feasible. On the other hand, being entrepreneurial but uncaring toward the environment, damages firm's standing with the customers (Provasnek et al., 2017). Against this back drop, the concept of sustainable corporate entrepreneurship can ensure the safe sailing of the firms. Sustainable corporate entrepreneurship is achieved when a firm along with attaining innovation in products, processes and strategies also achieve three sustainability goals of; responsible environmental management, social responsibility and economic performance (Miles et al., 2009). Large organizations need more innovative and creative products and processes to sustain and to get a competitive edge. Large scale manufacturing sector also focuses on developing new products, services, processes, technology, administrative techniques, techniques, practice, and competitive positions (ur Rahman, 2019; Thompson et al., 2020).

\section{Talent Management}

The war for talent and management of talent remain major challenges for organizations. Talent familiarity with fourth industrial revolution (4IR) advancement is needed to foster environmental sustainability (Bamel et al., 2020; Farndale et al., 2020; Ogbeibu et al., 2021). Environmental sustainability is a competitive advantage for contemporary organizations and that is why most of the organizations are willing to gain it (Ab Wahab, 2021; Atiku and Fapohunda, 2021). Besides, talent is considered a scarce, strategic asset and a source of competitive advantage (Harsch and Festing, 2020). Stemming from the resource-based view (RBV), skills may be understood as valuable, uncommon, inimitable, and non-substitutable, allowing the implementation of value-creating strategies and success of sustainable competitive advantage (Sparrow and Makram, 2015; Chadwick and Flinchbaugh, 2021).

The realization of employees as a source of competitive edge has given a strategic outlook to HR. Instead of managing day to day staffing through recruitment and training, HR was entrusted to ensure competitive advantage of the firm by attracting, hiring, and retaining the talented individuals. The effort to define talent management is preceded by the definition of talent itself. The talented individuals have mastery of the skills that place them among the top 10\% of the employees (Gagné, 2000). Along with their knowledge, skills, and competencies, they have a positive attitude toward their work (Tansley, 2011). In simple words, talent management is the management of talented individuals. But such a simplistic definitions hide more than it reveals. So, a comprehensive definition is required. Initially, talent management was considered to be grooming the talented ones and exiting the ones lacking in talent (Michaels et al., 2001). However, the use of talent management focusing on employees instead of position may not be theoretically sound. So, to improve the theoretical soundness of the definition, another definition focusing on position rather than person has been forwarded. According to this definition talent management is the systematic identification of key positions, development of a talent pool for the identified positions, development of the HR architect to fill these positions and finally ensuring the incumbents continued commitment to the organization (Collings and Mellahi, 2009; Collings et al., 2019). Talent management is found to be related to organizational performance (Ahmad Arif and Uddin, 2016).

\section{Organizational Engagement}

At personal level, work engagement is defined as a positive, fulfilling, work-related state of mind characterized by vigor, dedication and absorption (Bakker and Leiter, 2010; Schaufeli, 2012). As feelings are contagious therefore employees, finding their colleagues to be imbued with work engagement, catch the bug by interpreting and ascribing the collective meaning to prevailing work behavior (Seibert et al., 2004). So, building upon the personal level work engagement, organizational engagement has been defined as the shared perception of employees regarding their collective physical, cognitive and emotional involvement in their work (Barrick et al., 2015). As a collective resource for the firms, organizational engagement affects organizational performance (Barrick et al., 2015; Schneider et al., 2018).

Organizational members have a shared perception that members of the organization are engaged in their work (Khan et al., 2021a). Collective organizational engagement is an understudied topic for researchers and can help firms achieve and sustain higher performance (Barrick et al., 2015). To Trabucchi et al. (2020) organizational engagement is fundamental to motivate employees and their involement in innovation (Trabucchi et al., 2020). This positive state of mind brings positive attitudinal, behavioral, and work-related results among the employees (Saks, 2021). As a result, employees are willing to allocate extra time and resources to their organizations (Lee et al., 2018).

\section{Talent Management and Green Corporate Entrepreneurship}

Both the current performance of the firm and its future prospects are affected by its employees and their attitude (Long, 1980; Berberoglu, 2018). Firms with employees who are competent and willing can do wonder for their organizations. Talent management, from hiring to facilitating the employees, has the potential to affect green corporate entrepreneurship. Hiring the competent individuals desiring to work for the sustainable performance of the firm, and training them to further improve their competence to pursue green corporate entrepreneurship work to enable the organization to achieve this end. Corporate entrepreneurship is the organizational-led creative effort that emanates from the employees of the organization (Amberg and McGaughey, 2019). The creativity component, in any work, brings the uncertainty causing risk into it. Employees tend to avoid all those enterprises related risk because of the associated 
negative repercussions (Ratten, 2020). In such a situation, spurring employees to indulge in any risky enterprise is possible when employees feel that they are being actively nurtured and supported (Astrini et al., 2020). The current study purports that talent management practices ensure the employees of the support and equip them with the required resources to pursue corporate entrepreneurship. When an organization is caring, valuing, and supporting its employees, inundated with such respect, the employees in return build a trusting relationship with the organization. (Al Hammadi et al., 2020). The employees feel that such caring and supportive behavior readily indulges them even in a risky enterprise (Al Hammadi et al., 2020). In addition, organizations are applying talent management practices to equip employees with the required resources to accomplish innovation results (Sopiah et al., 2020). Employees, finding the organization to provide them with the required training and extending other exposures to enhance their performance, have the necessary skills and resources to invigorate their efforts to accomplish the goal of corporate entrepreneurship (Othman and Khalil, 2018).

Additionally, talent management is a process that works for the development of employees (Collings et al., 2015). The resulting positive benefits accrued to the employees work as favors extended to them. According to social exchange theory (SET), (Blau, 1964), individuals seek the opportunities to return the favor in the same currency. So, the obliged employees show their proclivity to indulge in activities valued by the organization (Blau, 1964). Enabling the firm to sustainably operate is one of the ways employees can return the favor extended to them by the organization. Due to its conceptual similarity with the above-mentioned constructs, corporate entrepreneurship can be expected to be influenced by talent management practices. In light of the existing theoretical underpinning and empirical evidence, the following hypothesis can be formed. So, in the light of SET, we can have the following hypothesis.

\section{H1: Talent management is related to green corporate entrepreneurship.}

\section{Talent Management and Organizational Engagement}

The relation between talent management and organizational engagement can be explained in three ways. First, the idea of talent management gives value to the employees (Murillo and King, 2019). Apart from hiring that is one time process, the other facets of talent management such as development and retention of employees continually work to cater to the needs of the employees (Collings et al., 2019). Furthermore, talent management works for the growth of the employees (Boštjančič and Slana, 2018). Finding themselves being facilitated and groomed, the employees value their work and organization positively and show increased level of absorption in their work in the context of the organization (Deery and Jago, 2015). Second, the process of talent management works as a favor extended to the employees (De Boeck et al., 2018). In return, the favored employees seek opportunities to return the favor. One of the ways to positively reciprocate the favor is to show enhanced organizational engagement (Blau, 1964).
Third, talent management works as a resource (Luna-Arocas et al., 2020). Employees who are resourceful have positive energy and they show more engagement both to their work and organization. Though talent management has not yet been related to organizational engagement, supportive HR practices, a facet of talent management, has been found to be related to employee engagement (Juhdi et al., 2013).

Talent management, on part of the organization, is the augmented care for the employees (Claus, 2019). Through talent management practices, firms strive to provide employees with extra care to retain them and provide them with training to enhance their skills and abilities (Cross Walker, 2020). The talent management practices, from the identification of key posts to whole-hearted efforts to retain the employees, strive to facilitate employees by providing them with care, learning opportunities, and resources. Such a caring attitude on the part of an organization is enough to overwhelm the employees (Hamilton and Davison, 2018) and they seek opportunities to return the favor. There are multiple ways for employees to return the favor. Employees can put more effort into their work. Employees can show more commitment toward the organization. In line with the above-mentioned constructs, employees can be highly engaged with the organization. According to social exchange theory, employees served by the organization will attempt to return the favor. One way to return the favor is to increase their organizational engagement (Blau, 1964). Researchers have found that employees have a heightened organizational engagement when firms are supportive to employees (Saks, 2021). Additionally, organizational engagement increases with improved HR practices (Afsar et al., 2020). Talent management is also a type of enhanced human resource. Therefore, the same effect of increased employee engagement can be attributed to talent management practices (Sopiah et al., 2020). Building upon the aforementioned discussion, the following hypothesis is proposed.

H2: Talent management is related to organizational engagement.

\section{Organizational Engagement and Green Corporate Entrepreneurship}

Engagement is a state characterized with pleasure and activation (Bakker and Oerlemans, 2011). Collectively, pleasure and activation give energy and drive to employees to pursue organization's objectives (Khan et al., 2021a). Organizational engagement is a positive state in which employees are not only ready to be actively involved in their work, but they also work for the goals of the organization. One of the pursued goals of the organization today is green corporate entrepreneurship (Miles et al., 2009). As mentioned earlier, organizationally engaged employees also engage them with the goals of the organization and actively pursue them, so it is proposed that organizational engagement will have effect on green corporate entrepreneurship.

One of the major purposes of strategies is to ensure the sustainability of a firm (Parente et al., 2020). A firm that can use its resources to meet the customers' current needs and plan for meeting their future needs can survive in the long run (Takata 
et al., 2020). Because of the uncertain future, firms are concerned about the business ideas that can cater to the customers' rising needs (Atiku and Abiola, 2020). Corporate entrepreneurship is one of the strategies to serve this purpose. Firms have realized that corporate entrepreneurship is employee-driven. Employees with their accumulated knowledge are in a position to indulge in CE (Belousova et al., 2020). Google uses its employees for this purpose. The moot point is why some organizations can use their employees to pursue corporate entrepreneurship while others cannot. One of the possible explanations lies in the organizational engagement of the employees. Firms with engaged employees have positive emotions so they both can reciprocally benefit each other (Pandey et al., 2020). Employee engagement is consist of two mechanism: attention (intellectually available and time given to a role) and concentration (to involve in a role to the best of his/her ability), (Peng et al., 2014). The presence of positive emotions increases the thought-action repertoire of the employees that result in an increased number of ideas and enables employees to vigorously follow their implementation, resulting in an increased number of corporate entrepreneurship activities (Belousova et al., 2020). Currently, there is no study that has explored the relation between organizational engagement and corporate entrepreneurship. In the light of the above discussed reasoning and empirical evidence, the following hypothesis is formed.

\section{H3: Organizational engagement and green corporate entrepreneurship.}

\section{Mediating Role of Organizational Engagement}

Trabucchi et al. argue that in this global competitive environment businesses have to improve productivity and one of the ways to do this is through employees. There is evidence that engaged employees are more, loyal, trusted, hard worker, and they are ready to go the "extra mile" for their organization. Employee engagement is linked with organization performance and employees are more enthusiastic about their jobs (Trabucchi et al., 2020). If the values and norms of an individual are associated with organization, then synergy of organization and employee creates engagement resultantly reciprocal beneficial for employee and organization outcome (Afsar et al., 2020). The social exchange theory (Blau, 1964) explains that in a mutual bond, if an employee finds connected and well-fit with the organization and its values, norms and standards, then the employee finds well-fit with the organization an employment. This validates the importance of developing employee engagement strategies for organizations and organizations be able to develop their sustainable competitive advantage through their talent (Nienaber, 2019).

Despite the well-represented theoretical understanding between talent management and corporate entrepreneurship and talent management and organizational engagement, the role of organizational engagement as a mediator between talent management and corporate entrepreneurship requires further explanation. Research also proves that talent management is positively related to organizational performance
(Mohammed, 2016; Bakytgul et al., 2019), employee retention (Pandita and Ray, 2018), and corporate entrepreneurship strategies (Ratten and Ferreira, 2016). Employees' engagement is playing a pivotal role in the development of organizations (Bakytgul et al., 2019). Employees' engagement increases organizational engagement and that ultimately results in increased organizational performance and job satisfaction (Rai and Maheshwari, 2020). Based on the social exchange theory (Blau, 1964), employees with talent are supported by organizations and keep them engaged and motivated. In return, the employees are coming up with creative and innovative ideas that can add value to organizations' products or services (Afsar et al., 2020).

Social exchange theory posits that an extended favor brings back a favor (Blau, 1964). Employees working in the organization regard their firm to be a personified entity and a favor extended to them is regarded a benevolence by the firm. The practices of talented management directed toward employees are meant, on one hand, to facilitate the employees (Ambrosius, 2018). On the other hand, the talent management practices groom the employees to improve their skills and knowledge of the work (Luna-Arocas et al., 2020). Employees regard both the aspects of talent management to be favors extended to them, and in return seek opportunities to reciprocate. One of the ways available to employees to reciprocate is to show more engagement in their work. The individual work engagement is the building block of collective organizational engagement. Pleased with the organizational policies toward them, employees begin to demonstrate high level of organizational engagement (Rofcanin et al., 2017). The engaged employees strive to serve their organization in multiple ways. Apart from being efficient in their work (Rofcanin et al., 2017), they search for new ventures ensuring the growth of their firm. Aware of the increased prominence of environmental concern, the employees, seeking to return the favor, indulge in corporate entrepreneurial activities that are environmentally friendly. Building upon the mentioned reasoning, the following hypothesis is formed.

H4: Organizational engagement mediates the relationship between talent management and green corporate entrepreneurship (Figure 1).

\section{METHODOLOGY}

\section{Sampling and Data Collection}

The study collected data from the individuals working in the large manufacturing firms of Pakistan. Initially, 400 potential respondents were approached from the manufacturing industry. The approached individuals were the ones working in the large manufacturing firms of the country. Out of the approached 400 employees, 323 responded and filled the questionnaire. The overall response rate is $81 \%$. The profile of the respondents is given in Table 1. The majority of the respondents were male $(79 \%)$ while the remaining $21 \%$ were female as shown in Table 1. Moreover, Table 1 shows that a small portion of $7 \%$ of respondents had 12 years (Intermediate) of qualification, besides this $38 \%$ of the respondents had bachelor degree and the 


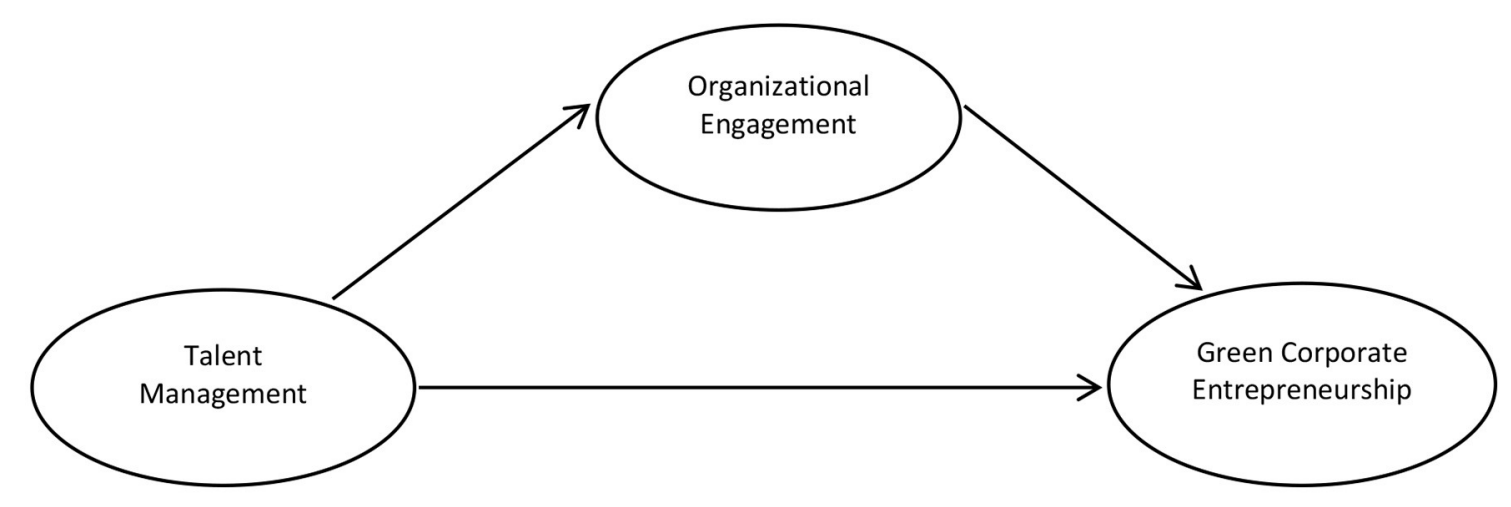

FIGURE 1 | Conceptual framework of the study.

TABLE 1 | Respondents profile.

\begin{tabular}{|c|c|c|c|}
\hline Variable & & $n(323)$ & \\
\hline \multirow[t]{2}{*}{ Gender } & Male & $79 \%$ & \\
\hline & Female & $21 \%$ & \\
\hline \multirow[t]{3}{*}{ Qualification } & Intermediate & $07 \%$ & \\
\hline & Bachelor & $38 \%$ & \\
\hline & Master & $54 \%$ & \\
\hline \multirow[t]{4}{*}{ Management level } & Line manager & $48 \%$ & \\
\hline & Middle manager & $35 \%$ & \\
\hline & Top manager & $15 \%$ & \\
\hline & & Mean & SD \\
\hline Age & & 33.37 & 9.256 \\
\hline Experience & & 9.47 & 8.525 \\
\hline
\end{tabular}

remaining 54\% were master degree holders. A larger portion of respondents came from line managers (48\%), while the portions of middle and top managers were 35 and 15\% respectively. Finally, Table 1 shows that the average age of the respondents was 33.37 years and their job experience was 9.47 years.

\section{Measure}

\section{Talent Management}

To measure talent management, the scale developed by Alkerdawy (2016) was adopted (Alkerdawy, 2016). The scale has 18 items that were measured on five points Likert scale where one means strongly disagree and five means strongly agree. One of the example items of talent management scale is: "Our organization attracts talent effectively."

\section{Green Corporate Entrepreneurship}

To measure green corporate entrepreneurship, the study adapted the scale developed by Zahra (Zahra, 1996). The original scale was meant to measure corporate entrepreneurship. For this study, the items of the scale were adapted to measure green corporate entrepreneurship. One of the adapted item is as follows: "Our organization has pioneered sustainable innovation in the industry." All the items were measured on five points Likert scale where one was used to denote "strongly disagree" and seven was used to denote "strongly agree."

\section{Organizational Engagement}

The organizational engagement scale is developed by Barrick et al. (2015). The scale has 0.6 items measured on Likert scale where one stands for strongly agree whereas five represents strongly agree. One of the example items of organizational engagement is "Employees in our organization really throw themselves into their work."

\section{FINDINGS}

\section{Measurement Model}

This study used PLS-SEM to analyze the collected data. PLSSEM has been widely used in a variety of fields in recent years with non-normal data, small sample sizes and the use of formative indicators being the most prominent reasons for its application (Hair et al., 2019). The popularity of structural equation modeling (SEM) has grown out of the need to test complete theories and concepts (Hair et al., 2014). According to Hair et al., currently covariance-based structural equation modeling (CB-SEM) is the dominant method for analyzing complex interrelationships between observed variables and latent variables (Hair et al., 2019). Much of SEM's success can be attributed to the method's ability to evaluate the measurement of latent variables, while also testing relationships between latent variables (Sarstedt et al., 2014). Moreover, reliability and validity are the two most important criteria used in PLS-SEM analysis to evaluate the outer model (Hair et al., 2014). Reliability is assessed using composite reliability (CR) while validity is measured through convergent validity average variance extracted (AVE), and discriminant validity using Fornell and Larcker (1981) criterion and indicator's outer loadings.

The constructs used in the study were evaluated for their reliability and validity. Reliability is a measure of consistency, and the measures used were Cronbach's alpha and composite reliability. The minimum acceptable level for both the measures is 0.7 (Holmes-Smith et al., 2006). Validity indicates the ability the measure what it aims to measure. Convergent and 
TABLE 2 | Reliability and validity.

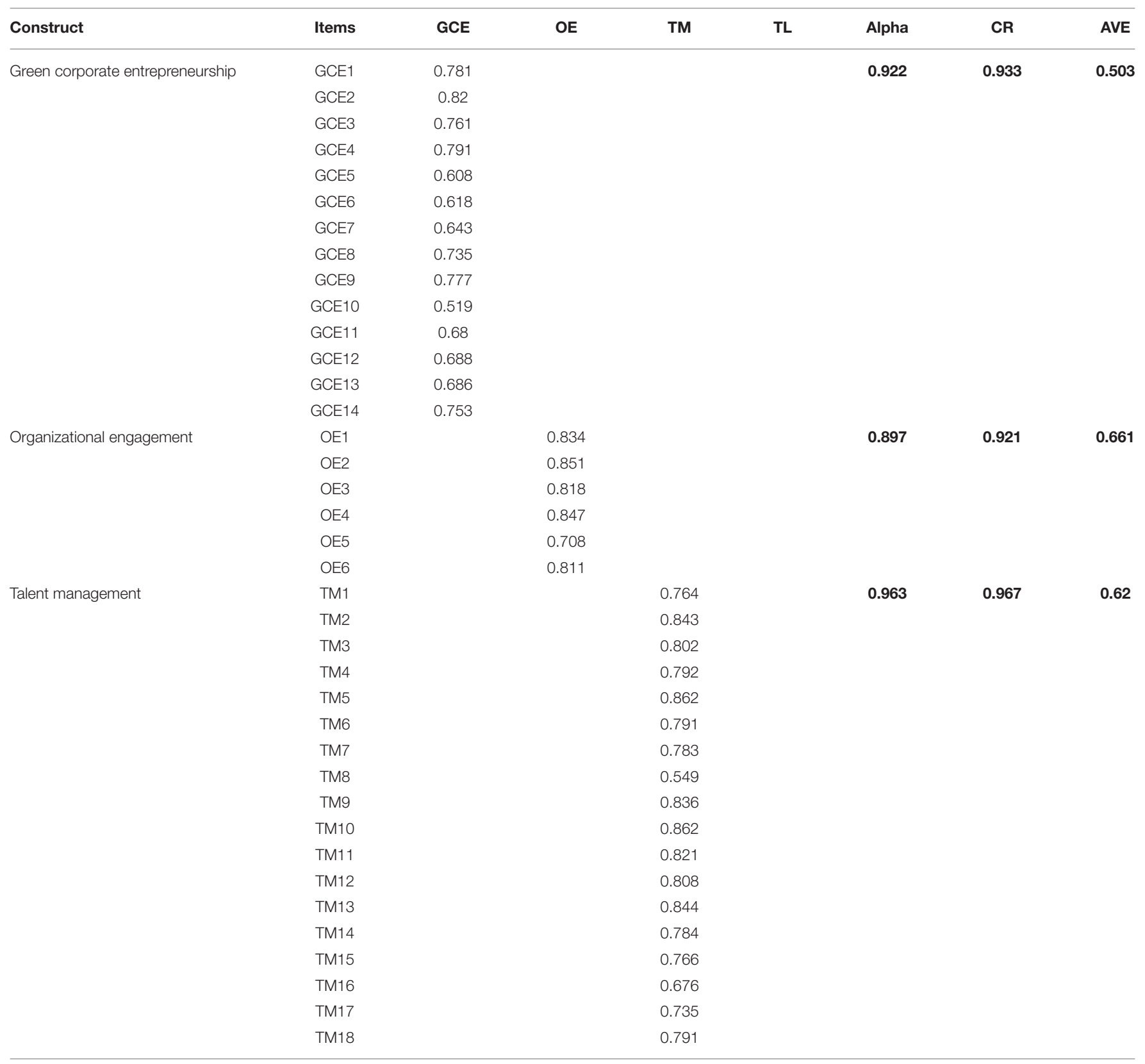

discriminant validity were checked at the item as well as at the construct level. Item loading was used for item-level convergent validity, and the minimum value for item loading is 0.7. AVE (Average Variance Extracted) was used for construct level validity, and the minimum acceptable value of AVE is 0.5 (Fornell and Larcker, 1981; Henseler et al., 2009; Hair et al., 2010). Discriminant validity was also measured at the item and construct level, which is the ability of a construct to stand out from the different measures. For item level discriminant validity, the loadings are required to be more than cross-loadings (Fornell and Larcker, 1981; Bagozzi and Yi, 1988). Whereas, for construct level, both Fornell and Larcker and HTMT criterion are used.
The results contained in Table 2 shows the used constructs to be reliable and valid. The constructs used in the model namely; green corporate entrepreneurship, talent management and organizational engagement were found to be reliable as the Cronbach's Alpha (Alpha) and composite reliability (CR) were more than the minimum acceptable value of 0.7 . The lowest value of alpha (0.897) and CR (0.921) were found for organizational engagement as shown in Table 2. Item level and construct level convergent validity were evaluated through the values of item loadings and average variance extracted (AVE). Though some items had loadings of less than the recommended threshold of 0.7 , at the construct level AVEs were more than 0.5 , the lower bound for the construct to have convergent validity. The lowest 
TABLE 3 | Descriptive statistics and discriminant validity

\begin{tabular}{|c|c|c|c|c|c|c|}
\hline \multirow[b]{2}{*}{ Variable } & \multirow[b]{2}{*}{ M } & \multirow[b]{2}{*}{ SD } & \multicolumn{2}{|c|}{ Correlation } & \multicolumn{2}{|c|}{ HTMT Ratios } \\
\hline & & & (1) & (2) & (1) & (2) \\
\hline $\begin{array}{l}\text { Organizational } \\
\text { engagement (1) }\end{array}$ & 3.822 & 0.855 & & & & \\
\hline $\begin{array}{l}\text { Green corporate } \\
\text { entrepreneurship } \\
\text { (2) }\end{array}$ & 3.626 & 0.778 & $0.679^{\star \star}$ & & 0.749 & \\
\hline $\begin{array}{l}\text { Talent } \\
\text { management (3) }\end{array}$ & 3.732 & 0.878 & $0.753^{\star \star}$ & $0.790^{\star *}$ & 0.812 & 0.842 \\
\hline
\end{tabular}

${ }^{\star *}$ Correlation is significant at the 0.01 level (2-tailed).

value of AVE was found for green corporate entrepreneurship $(\mathrm{AVE}=0.503)$ as given in Table 2. Finally, to evaluate the constructs for the discriminant validity, hetero-trait mono-trait (HTMT) ratios were computed for the constructs used in the study. As shown in Table 3, all the ratios are $<0.85$, the stricter upper bound for the constructs to be declared different (Henseler et al., 2015).

\section{Structural Model}

Testing the structural model is possible when the constructs used in the model are related. To evaluate this requirement, interconstructs correlations were computed. The results, given in Table 3, demonstrate that the constructs are either moderately or strongly related; thus, paving the way for model testing being described here. The minimum value of correlation is found between organizational engagement and green corporate entrepreneurship $(r=0.679)$. The model proposed in the study has four hypotheses. The first hypothesis conjectured a relationship between talent management and green corporate entrepreneurship. The results obtained supported the claim ( $\beta=0.669, p=0.000)$. The second hypothesis, claiming a relationship between talent management and organizational engagement, was also found to be significant $(\beta=0.765$, $p=0.000)$. Similarly, the third hypothesis purporting a relationship between organizational engagement and green corporate entrepreneurship turned out to be significant ( $\beta=$ $0.181, p=0.002)$. Along with the reported three direction relationship tested, the study also explicated the mediating role of organizational engagement relating talent management with green corporate entrepreneurship. The results, shown in Table 4, provide support to the mediating role of organizational engagement $(\beta=0.139, p=0.003)$.

\section{DISCUSSION}

The study was undertaken to explicate the role of talent management in affect green corporate entrepreneurship. Additionally, the study intended to fathom the mediating role of organizational engagement relating talent management with green corporate entrepreneurship. In total, the study tested four hypotheses. The first hypothesis, purporting a relationship between talent management and green corporate entrepreneurship, was found to be significant. This finding is in line with the earlier findings suggesting a relation between talent management and employee performance (Mensah, 2015; Choi and Cho, 2021). The second hypothesis delineated a relationship between talent management and organizational engagement. The obtained results showed the claim was supported in line with the earlier studies depicting a relationship between HR practices and organizational engagement (Juhdi et al., 2013). The findings of the study are being discussed in the subsequent paragraphs.

The first hypothesis proposed a relationship between talent management practices and green corporate entrepreneurship. The findings supported the conjuncture, which is in line with the findings of the earlier studies (Al Hammadi et al., 2020; Astrini et al., 2020; Ratten, 2020; Sopiah et al., 2020). Though no study has attempted to divulge the role of talent management practices in affecting green corporate entrepreneurship, earlier studies had pointed to the relation between talent management practices and innovative work behavior and creativity (Othman and Khalil, 2018). The finding of the current study corroborates with the earlier finding relating to talent management practices and creativity (Sopiah et al., 2020). The second hypothesis of the study proposed a relation between talent management practices and organizational engagement. Although there is a void of literature on the relationship between talent management practices and organizational engagement; some studies are exhibiting the relationship between a supportive organization and organizational engagement (De Boeck et al., 2018; Afsar et al., 2020; Luna-Arocas et al., 2020; Saks, 2021). The finding of the current study is in line with the findings of aforementioned researchers. The third hypothesis asserting a relationship between organizational engagement and green corporate entrepreneurship was also synched with the earlier studies that had found organizational engagement to be related to other organizational performances (Srivastava et al., 2014; Barrick et al., 2015; Kazimoto, 2016). Besides the abovediscussed direction relationship, the study endeavored to unfurl the mediating role of organizational engagement in talent management and green corporate entrepreneurship. Though, there is no current study that has found such a mediating role for organizational engagement, the current study found organizational engagement to be mediating the relation.

Finally, talent management was related to organizational engagement in the light of existing evidence and theory. The final direct relation between talent management and green corporate entrepreneurship was found to be substantiated. Apart from their significant relation with green corporate entrepreneurship; talent management and green corporate entrepreneurship were related to organizational engagement. The findings showed that organizational engagement mediated the relationship between talent management and green corporate entrepreneurship; thus, affirming the role of positive emotions and resources. Talent management triggered engagement and innovativeness in employees pushes the employees to return the favor, as described in social exchange theory (Blau, 1964), by indulging in innovation behavior. Positive emotions and resources increased because indulgence in organizational engagement helps employees submit to corporate entrepreneurship. 
TABLE 4 | Structural model.

\begin{tabular}{lcccc}
\hline Relation & Coefficient & SE & t-test & $\boldsymbol{p}$-value \\
\hline Talent management GCE & 0.669 & 0.049 & 13.634 & 0.000 \\
Talent management Organizational engagement & 0.765 & 0.028 & 27.761 & 0.000 \\
Organizational engagement GCE & 0.181 & 0.058 & 3.099 & 0.002 \\
Talent management organizational engagement GCE & 0.139 & 0.047 & 2.981 & 0.003 \\
\hline
\end{tabular}

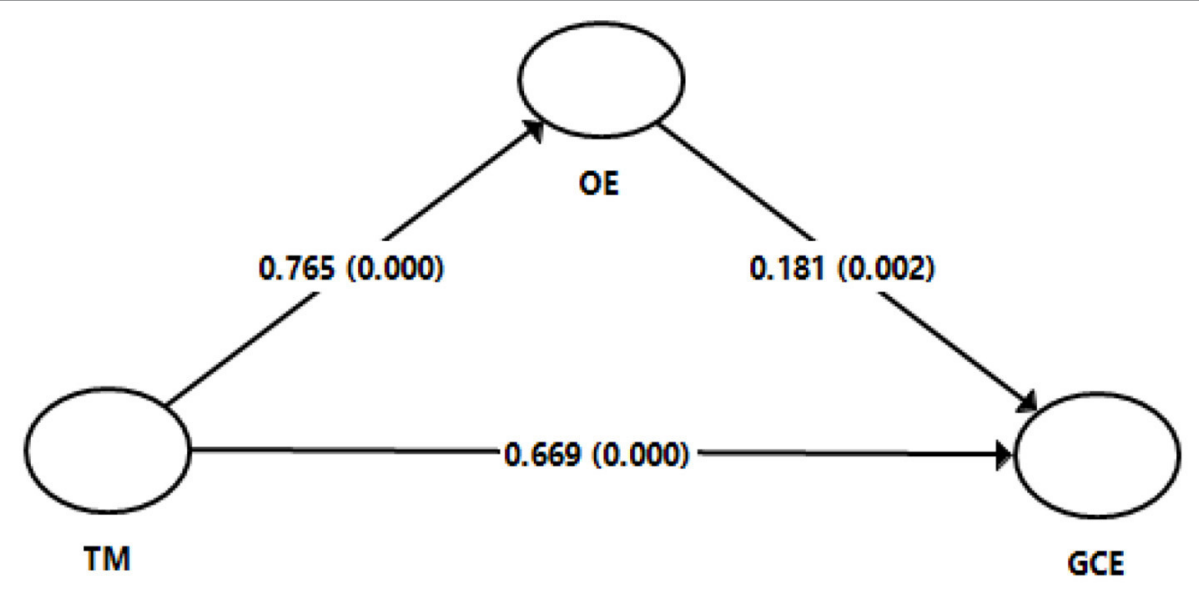

GCE, Green Corporate Entrepreneurship; TM, Talent Management; OE, Organizational Engagement; GCE, Green Corporate Entrepreneurship.

\section{THEORETICAL CONTRIBUTION}

The current study makes two contributions to existing knowledge. First, from the lens of social exchange theory, individuals reciprocate to the favor extended to them. The practices of talent management are intended to groom and develop the employees. Responding to these practices and the associated benefits, employees are inclined to indulge in extrarole behavior meant to benefit the organization. Green corporate entrepreneurship is one such behaviors that are manifested by the employees in order to return the favor extended to them. Second, the study unfurled the mediating role of organizational engagement relating talent management practices to green corporate entrepreneurship. This finding is also in line with social exchange theory. Employees encouraged by the employee centered practices tend to reciprocate positively to the positive overtures of the firm and as a result show higher organizational engagement that leads organizational specific extra-role behavior such as green corporate entrepreneurship.

\section{MANAGERIAL IMPLICATIONS}

The findings of the study has three managerial implications. First, the use of talent management can be made for giving a surge to organizational engagement. There is evidence suggesting organizational engagement improve organizational performance (Barrick et al., 2015; Bakytgul et al., 2019). Firms, by giving a push to organizational engagement can reap these benefits. In the context of COVID-19, the idea of stimulating organizational engagement becomes more important as the increased engagement will ensure employees' inclination to indulge in pro-organizational behavior. Second, the organizations can harness the creative potential of their employees through talent management practices. Attracting the talent, further developing it and facilitating it to pursue green corporate entrepreneurship. Third, organizations while further grooming the talented individuals can imbibe them with the rising importance of sustainability. As a result, employees with talent may consider environmental aspects of their innovative pursuit thus ensuring green corporate entrepreneurship.

\section{LIMITATION AND FUTURE AREAS OF STUDIES}

Reflecting on a journey always reveals what could have been improved; the same is also true for the current study. At the end of the study, we find the study to be infected with some limitations. First, the study collected the data only from employees; the process is safe as long as it is regarding the practices of management of the behavior of the leadership, but data collection from employees regarding their performance such as corporate entrepreneurship is prone to self-reporting bias (MacKenzie and Podsakoff, 2012). Future studies can go for employee-manager dyads to reduce common method error. Second, the current study collected the data at a single point; such a procedure does not allow for the cause to register its effect. To improve the claim of causality, the studies in the future can collect data for cause and effects at two different times. Third, the current 
study has collected data from the large-scale manufacturing sector. The narrow focus limits the generalizability of the study. Researchers in future, studying the same relation, can widen the population to improve the generalizability of the findings.

\section{DATA AVAILABILITY STATEMENT}

The raw data supporting the conclusions of this article will be made available by the authors, without undue reservation.

\section{REFERENCES}

Ab Wahab, M. (2021). Is an unsustainability environmentally unethical? Ethics orientation, environmental sustainability engagement and performance. $J$. Clean. Prod. 294:126240. doi: 10.1016/j.jclepro.2021.126240

Abubakar, A. (2020). Coronavirus (COVID-19): effect and survival strategy for businesses. J. Econ. Bus. 3:12. doi: 10.31014/aior.1992.03.02.229

Afsar, B., Al-Ghazali, B. M., Cheema, S., and Javed, F. (2020). Cultural intelligence and innovative work behavior: the role of work engagement and interpersonal trust. Eur. J. Innov. Manag. 24, 1082-1109. doi: 10.1108/EJIM-01-2020-0008

Ahmad Arif, A., and Uddin, M. R. (2016). talent management and organizational performance: an empirical study in retail sector in Sylhet City, Bangladesh. IOSR J. Bus. Manag. 18, 11-18. doi: 10.9790/487X-1810041118

Al Hammadi, H. A., Noor, M. A. B. M., and Rosdi, S. A. M. (2020). The moderating role of leadership in the talent management and employee retention of Abu Dhabi department of education and knowledge. Eur. J. Econ. Bus. Stud. 6, 109-117.

Alkerdawy, M. M. A. (2016). The relationship between human resource management ambidexterity and talent management: the moderating role of electronic human resource management. Int. J. Bus. Res. 9, 80-94. doi: 10.5539/ibr.v9n6p80

Amberg, J. J., and McGaughey, S. L. (2019). Strategic human resource management and inertia in the corporate entrepreneurship of a multinational enterprise. Int. J. Hum. Resour. Manag. 30, 759-793. doi: 10.1080/09585192.2016.1192051

Ambrosius, J. (2018). Strategic talent management in emerging markets and its impact on employee retention: evidence from Brazilian MNCs. Thunderbird Int. Bus. Rev. 60, 53-68. doi: 10.1002/tie.21799

Astrini, N., Rakhmawati, T., Sumaedi, S., Bakti, I., Yarmen, M., and Damayanti, S. (2020). Innovativeness, proactiveness, and risk-taking: corporate entrepreneurship of Indonesian SMEs. IOP Conf. Ser.: Mater. Sci. Eng. 722:012037. doi: 10.1088/1757-899X/722/1/012037

Atiku, S. O., and Abiola, A. A. (2020). "Strategic capabilities for the sustainability of small, medium, and micro enterprises," in Reshaping Entrepreneurship Education with Strategy and Innovation (Hershey, PA: IGI Global), 17-44. doi: 10.4018/978-1-7998-3171-6.ch002

Atiku, S. O., and Fapohunda, T. (eds.). (2021). "Workplace green behavior for sustainable competitive advantage," in Human Resource Management Practices for Promoting Sustainability (Hershey, PA: IGI Global). doi: 10.4018/978-1-7998-4522-5

Bagozzi, R. P., and Yi, Y. (1988). On the evaluation of structural equation models. J. Acad. Mark. Sci. Rev. 16, 74-94. doi: 10.1007/BF027 23327

Bakker, A. B., and Leiter, M. P. (eds.). (2010). Work Engagement: A Handbook of Essential Theory and Research. Hove: Psychology Press. doi: $10.4324 / 9780203853047$

Bakker, A. B., and Oerlemans, W. G. M. (2011). Subjective Well-being in Organizations. Oxford: Oxford University Press. doi: 10.1093/oxfordhb/9780199734610.013.0014

Bakytgul, T. B., Ahmed, M., and Kim, Y. (2019). Corporate entrepreneurship and organizational performance: the moderating role of organizational engagement. Ann. Contemp. Dev. Manag. HR. 1, 39-45. doi: 10.33166/ACDMHR.2019.01.005

\section{AUTHOR CONTRIBUTIONS}

The authors contributed to the study conception and design. Literature review, methodology, search of relevant articles, data collection, analysis, discussion, results, and conclusion were performed by EK and MM. The first draft of the manuscript was written by EK. MM and ZS thoroughly checked the first draft and improved the first draft. All authors commented on previous versions of the manuscript. All three authors have read and approved the final manuscript.

Bamel, U., Pereira, V., Del Giudice, M., and Temouri, Y. (2020). The extent and impact of intellectual capital research: a two decade analysis. J. Intellect. Cap. doi: 10.1108/JIC-05-2020-0142

Barrick, M. R., Thurgood, G. R., Smith, T. A., and Courtright, S. H. (2015). Collective organizational engagement: linking motivational antecedents, strategic implementation, and firm performance. Acad. Manag. Ann. 58, 111-135. doi: 10.5465/amj.2013.0227

Belousova, O., Hattenberg, D. Y., and Gailly, B. (2020). "Corporate entrepreneurship: from structures to mindset," in Organizational Mindset of Entrepreneurship (Berlin: Springer), 211-233. doi: 10.1007/978-3-030-36951-4_10

Berberoglu, A. (2018). Impact of organizational climate on organizational commitment and perceived organizational performance: empirical evidence from public hospitals. BMC Health Serv. Res. 18:399. doi: 10.1186/s12913-018-3149-z

Blau, P. M. (1964). Justice in social exchange. Sociol. Inq. 34, 193-206. doi: 10.1111/j.1475-682X.1964.tb00583.x

Bos-Nehles, A. C., and Veenendaal, A. A. R. (2019). Perceptions of HR practices and innovative work behavior: the moderating effect of an innovative climate. Int. J. Hum. Resour. Manag. 30, 2661-2683. doi: 10.1080/09585192.2017.1380680

Boštjančič, E., and Slana, Z. (2018). The role of talent management comparing medium-sized and large companies-major challenges in attracting and retaining talented employees. Front. Psychol. 9:1750. doi: 10.3389/fpsyg.2018.01750

Chadwick, C., and Flinchbaugh, C. (2021). Searching for competitive advantage in the HRM-firm performance relationship. Acad. Manag. Perspect. 35, 181-207. doi: 10.5465/amp.2018.0065

Choi, H.-J., and Cho, W.-S. (2021). The causal relationships among talent management (TM), extra-role behavior and work engagement in the hotel industry. J. Culin. Sci. Technol. 27, 85-94.

Christos, C. (2017). The Effect of Motivations for Ecological Responsiveness (ER) on Intrapreneurship in South Africa. University of the Witwatersrand

Claus, L. (2019). HR disruption-time already to reinvent talent management. BRQ Bus. Res. Q. 22, 207-215. doi: 10.1016/j.brq.2019. 04.002

Collings, D. G., and Mellahi, K. (2009). Strategic talent management: a review and research agenda. Hum. Resour. Manag. Rev. 19, 304-313. doi: 10.1016/j.hrmr.2009.04.001

Collings, D. G., Mellahi, K., and Cascio, W. F. (2019). Global talent management and performance in multinational enterprises: a multilevel perspective. J. Manage. 45, 540-566. doi: 10.1177/0149206318 757018

Collings, D. G., Scullion, H., and Vaiman, V. (2015). Talent management: progress and prospects. Hum. Resour. Manag. Rev. 25, 233-235. doi: 10.1016/j.hrmr.2015.04.005

Cross Walker, T. (2020). Inclusive talent management in the public sector: theory and practice. Transnatl. Corp. Rev. 12, 1-9. doi: 10.1080/19186444.2020.1741296

De Boeck, G., Meyers, M. C., and Dries, N. (2018). Employee reactions to talent management: assumptions vs. evidence. J. Organ. Behav. 39, 199-213. doi: $10.1002 /$ job.2254 
Deery, M., and Jago, L. (2015). Revisiting talent management, work-life balance and retention strategies. Int. J. Contemp. Hosp. Manag. 27, 453-472. doi: 10.1108/IJCHM-12-2013-0538

Denning, S. (2021). Why management models are crucial to the success of business models. Strategy Leadersh. 49, 9-13. doi: 10.1108/SL-02-2021-0011

Dwivedi, Y. K., Hughes, D. L., Coombs, C., Constantiou, I., Duan, Y., Edwards, J. S., et al. (2020). Impact of COVID-19 pandemic on information management research and practice: transforming education, work and life. Int. J. Inf. Manage. 55:102211. doi: 10.1016/j.ijinfomgt.2020.102211

Ehnert, I. (2011). "Sustainability and HRM: a model and suggestions for future research," in The Future of Employment Relations (Berlin: Springer), 215-237. doi: 10.1057/9780230349421_12

Farndale, E., McDonnell, A., Scholarios, D., and Wilkinson, A. (2020). Human resource management journal: a look to the past, present, and future of the journal and HRM scholarship. Hum. Resour. Manag. J. 30, 1-12. doi: 10.1111/1748-8583.12275

Fornell, C., and Larcker, D. F. (1981). Evaluating structural equation models with unobservable variables and measurement error. J. Mark. Res. 18, 39-50. doi: $10.1177 / 002224378101800104$

Gagné, F. (2000). "Understanding the complex choreography of talent development through DMGT-based analysis," in International Handbook of Giftedness and Talent, Vol. 2, eds K. A. Heller, F. J. Mönks, R. Subotnik, and R. J. Sternberg (Amsterdam: Elsevier), 67-79. doi: 10.1016/B978-008043796-5/50005-X

Gardas, B. B., Mangla, S. K., Raut, R. D., Narkhede, B., and Luthra, S. (2019). Green talent management to unlock sustainability in the oil and gas sector. J. Clean. Prod. 229, 850-862. doi: 10.1016/j.jclepro.2019.05.018

Guadamillas, F., Donate, M. J., and de Pablo, J. D. S. (2008). Knowledge management for corporate entrepreneurship and growth: a case study. Knowl. Process. Manag. 15, 32-44. doi: 10.1002/kpm.297

Hair, F. J. Jr., Sarstedt, M., Hopkins, L., and Kuppelwieser, G. V. (2014). Partial least squares structural equation modeling (PLS-SEM): an emerging tool in business research. Eur. Bus. Rev. 26, 106-121. doi: 10.1108/EBR-10-2013-0128

Hair, J. F., Black, W., C., Babin, B., J., Anderson, R. (2010). Multivariate Data Analysis, 7th Edn. Hoboken, NJ: Prentice Hall.

Hair, J. F., Risher, J. J., Sarstedt, M., and Ringle, C. M. (2019). When to use and how to report the results of PLS-SEM. Eur. Bus. Rev. 31, 2-24. doi: 10.1108/EBR-11-2018-0203

Hamilton, R. H., and Davison, H. K. (2018). The search for skills: knowledge stars and innovation in the hiring process. Bus. Horiz. 61, 409-419. doi: 10.1016/j.bushor.2018.01.006

Harsch, K., and Festing, M. (2020). Dynamic talent management capabilities and organizational agility-a qualitative exploration. Hum. Resour. Manag. 59, 43-61. doi: 10.1002/hrm.21972

Hayton, J. C. (2005). Promoting corporate entrepreneurship through human resource management practices: a review of empirical research. Hum. Resour. Manag. Rev. 15, 21-41. doi: 10.1016/j.hrmr.2005.01.003

Henseler, J., Ringle, C. M., and Sarstedt, M. (2015). A new criterion for assessing discriminant validity in variance-based structural equation modeling. J. Acad. Mark. Sci. Rev. 43, 115-135. doi: 10.1007/s11747-014-0403-8

Henseler, J., Ringle, C. M., and Sinkovics, R. R. (2009). "The use of partial least squares path modeling in international marketing, in Advances in International Marketing, Vol. 20, eds R. R. Sinkovics, and P. N. Ghauri (Bingley: Emerald Group Publishing Limited), 277-319. doi: 10.1108/S1474-7979(2009)0000020014

Holmes-Smith, P., Coote, L., and Cunningham, E. (2006). Structural Equation Modeling: From the Fundamentals to Advanced Topics. Melbourne: School Research.

Jiang, P., Fan, Y. V., and Klemeš, J. J. (2021). Impacts of COVID-19 on energy demand and consumption: challenges, lessons and emerging opportunities. Appl. Energy 285:116441. doi: 10.1016/j.apenergy.2021.116441

Juhdi, N., Pawan, F., and Hansaram, R. M. K. (2013). HR practices and turnover intention: the mediating roles of organizational commitment and organizational engagement in a selected region in Malaysia. Int. J. Hum. Resour. Manag. 24, 3002-3019. doi: 10.1080/09585192.2013.763841

Kabir, M. N. (2019). "Entrepreneurs and entrepreneurship," in Knowledge-Based Social Entrepreneurship (Berlin: Springer), 207-244. doi: 10.1057/978-1-137-34809-8_7
Kazimoto, P. (2016). Employee engagement and organizational performance of retails enterprises. Am. J. Ind. Bus. Manag. 6, 516-525. doi: 10.4236/ajibm.2016.64047

Khan, M. M., Mubarak, S., and Islam, T. (2020). Leading the innovation: role of trust and job crafting as sequential mediators relating servant leadership and innovative work behavior. Eur. J. Innov. Manag. doi: 10.1108/EJIM-05-2020-0187. [Epub ahead of print].

Khan, M. M., Mubarik, M. S., Ahmed, S. S., Islam, T., Khan, E., Rehman, A., et al. (2021a). My meaning is my engagement: exploring the mediating role of meaning between servant leadership and work engagement. Leadersh. Organ. Dev. J. 42, 926-941. doi: 10.1108/LODJ-08-2020-0320

Khan, M. M., Mubarik, M. S., Islam, T., Rehman, A., Ahmed, S. S., Khan, E., et al. (2021b). How servant leadership triggers innovative work behavior: exploring the sequential mediating role of psychological empowerment and job crafting. Eur. J. Innov. Manag. doi: 10.1108/EJIM-09-2020-0367. [Epub ahead of print].

Kühn, C., Eymann, T., Urbach, N., and Schweizer, A. (2016). From professionals to entrepreneurs: human Resources practices as an enabler for fostering corporate entrepreneurship in professional service firms. Ger. J. Hum. Resour. 30, 125-154. doi: 10.1177/2397002216632134

Kuratko, D. F. (2017). “Corporate entrepreneurship and innovation: today's leadership challenge," in The Wiley Handbook of Entrepreneurship, eds G. Ahmetoglu, T. Chamorro-Premuzic, B. Klinger, and T. Karcisky (Hoboken, NJ: John Wiley and Sons), 293-311. doi: 10.1002/9781118970812.ch14

Lee, M. C. C., Idris, M. A., and Tuckey, M. (2018). Supervisory coaching and performance feedback as mediators of the relationships between leadership styles, work engagement, and turnover intention. Hum. Resour. Dev. Int. 22, 1-26. doi: 10.1080/13678868.2018.1530170

Long, R. J. (1980). Job attitudes and organizational performance under employee ownership. Acad. Manag. J. 23, 726-737. doi: 10.5465/255559

Luna-Arocas, R., Danvila-Del Valle, I., and Lara, F. J. (2020). Talent management and organizational commitment: the partial mediating role of pay satisfaction. Int. Employ. Relat. 42, 863-881. doi: 10.1108/ER-11-2019-0429

MacKenzie, S. B., and Podsakoff, P. M. (2012). Common method bias in marketing: causes, mechanisms, and procedural remedies. J. Retail. 88, 542-555. doi: 10.1016/j.jretai.2012.08.001

Maritz, A., Perenyi, A., de Waal, G., and Buck, C. (2020). Entrepreneurship as the Unsung hero during the current COVID-19 economic crisis: Australian perspectives. Sustainability 12:4612. doi: 10.3390/su12114612

Martinez-Martinez, A., Cegarra-Navarro, J.-G., Garcia-Perez, A., and Wensley, A. (2019). Knowledge agents as drivers of environmental sustainability and business performance in the hospitality sector. Tour. Manag. 70, 381-389. doi: 10.1016/j.tourman.2018.08.030

Martín-Rojas, R., Garrido-Moreno, A., and García-Morales, V. J. (2020). Fostering corporate entrepreneurship with the use of social media tools. J. Bus. Res. 112, 396-412. doi: 10.1016/j.jbusres.2019.11.072

Mayer, H., and Motoyama, Y. (2020). Entrepreneurship in small and medium-sized towns. Entrepreneurship Reg. Dev. 32, 467-472. doi: 10.1080/08985626.2020.1798556

Mensah, J. K. (2015). A “coalesced framework" of talent management and employee performance: for further research and practice. Int. J. Product. Perform. Manag. 64, 544-566. doi: 10.1108/IJPPM-07-2014-0100

Mensah, J. K. (2019). Talent management and talented employees' attitudes: mediating role of perceived organisational support. Int. Rev. Adm. Sci. 85, 527-543. doi: 10.1177/0020852319844318

Michaels, E., Handfield-Jones, H., and Axelrod, B. (2001). The War for Talent. Boston, MA: Harvard Business Press.

Miles, M. P., Munilla, L. S., and Darroch, J. (2009). Sustainable corporate entrepreneurship. Int. Entrepreneurship Manag. J. 5, 65-76. doi: 10.1007/s11365-008-0074-3

Mohammed, A. (2016). The impact of talent management on employee engagement, retention and value addition in achieving organizational performance. Int. J. Eng. Manag. 1, 142-152.

Mujtaba, M., and Mubarik, M. S. (2021). Talent management and organizational sustainability: role of sustainable behaviour. Int. J. Organ. Anal. doi: 10.1108/IJOA-06-2020-2253

Murillo, E., and King, C. (2019). Why do employees respond to hospitality talent management: an examination of a Latin American restaurant chain. Int. J. Contemp. Hosp. Manag. 31, 4021-4042. doi: 10.1108/IJCHM-10-2018-0871 
Mustafa, M., Richards, J. J., and Ramos, H. M. (2013). High performance human resource practices and corporate entrepreneurship: the mediating effect of middle managers knowledge collecting and donating behaviour. Asian Acad. Manag. J. 18:17.

Nienaber, H. (2019). Employee engagement: driving strategy implementation through dimensions of organisation. J. Manag. Organ. 1-21. doi: $10.1017 /$ jmo.2019.22

Ogbeibu, S., Chiappetta Jabbour, C. J., Burgess, J., Gaskin, J., and Renwick, D. W. S. (2021). Green talent management and turnover intention: the roles of leader STARA competence and digital task interdependence. J. Intellect. Cap. doi: 10.1108/JIC-01-2021-0016. [Epub ahead of print].

Othman, A. A. E., and Khalil, M. H. M. (2018). Lean talent management: a novel approach for increasing creativity in architectural design firms. Eng. Constr. Archit. Manag. 25, 1355-1375. doi: 10.1108/ECAM-07-2017-0139

Pandey, J., Gupta, M., and Hassan, Y. (2020). Intrapreneurship to engage employees: role of psychological capital. Manag. Decis. 59, 1525-1545. doi: 10.1108/MD-06-2019-0825

Pandita, D., and Ray, S. (2018). Talent management and employee engagementa meta-analysis of their impact on talent retention. Ind. Commer. Train. 50, 185-199. doi: 10.1108/ICT-09-2017-0073

Parente, R., El Tarabishy, A., Botti, A., Vesci, M., and Feola, R. (2020). Humane entrepreneurship: some steps in the development of a measurement scale. J. Small Bus. Manag. 59, 1-25. doi: 10.1080/00472778.2020.1717292

Peng, J.-C., Lee, Y.-L., and Tseng, M.-M. (2014). Person-organization fit and turnover intention: exploring the mediating effect of work engagement and the moderating effect of demand-ability fit. J. Nurs. Res. 22, 1-11. doi: 10.1097/jnr.0000000000000019

Peschl, H., Deng, C., and Larson, N. (2020). Entrepreneurial thinking: a signature pedagogy for an uncertain 21st century. Int. J. Manag. Educ. 19, 1-14. doi: 10.1016/j.ijme.2020.100427

Provasnek, A. K., Schmid, E., Geissler, B., and Steiner, G. (2017). Sustainable corporate entrepreneurship: performance and strategies toward innovation: performance and strategies toward innovation. Bus. Strategy Environ. 26, 521-535. doi: 10.1002/bse.1934

Rai, A., and Maheshwari, S. (2020). Exploring the mediating role of work engagement between the linkages of job characteristics with organizational engagement and job satisfaction. Manag. Res. Rev. 44, 133-157. doi: 10.1108/MRR-10-2019-0442

Ratten, V. (2020). Coronavirus and international business: an entrepreneurial ecosystem perspective. Thunderbird Int. Bus. Rev. 62, 629-634. doi: 10.1002/tie.22161

Ratten, V., and Ferreira, J. (2016). Global talent management and corporate entrepreneurship strategy. Glob. Talent Manag. Staff. 32, 151-165. doi: 10.1108/S1876-066X20160000032006

Rofcanin, Y., Las Heras, M., and Bakker, A. B. (2017). Family supportive supervisor behaviors and organizational culture: effects on work engagement and performance. J. Occup. Health Psychol. 22, 207-217. doi: 10.1037/ocp0000036

Sadat, S. H., and Nasrat, S. (2020). The practice of open innovation by SMEs in the food industry. J. Occup. Health Psychol. 8, 26-46. doi: 10.24840/2183-0606_008.002_0004

Saks, A. M. (2021). Caring human resources management and employee engagement. Hum. Resour. Manag. Rev. 100835. doi: 10.1016/j.hrmr.2021.100835

Salau, O., Osibanjo, A., Adeniji, A., Oludayo, O., Falola, H., Igbinoba, E., et al. (2018). Data regarding talent management practices and innovation performance of academic staff in a technology-driven private university. Data Br. 19, 1040-1045. doi: 10.1016/j.dib.2018.05.081

Sarstedt, M., Ringle, C. M., and Hair, J. F. (2014). PLS-SEM: looking back and moving forward. Long Range Plan. 47, 132-137. doi: 10.1016/j.lrp.2014.02.008

Schaufeli, W. (2012). Work engagement: what do we know and where do we go? Rom. J. Exp. Appl. Psychol. 14, 3-10.

Schneider, B., Yost, A. B., Kropp, A., Kind, C., and Lam, H. (2018). Workforce engagement: what it is, what drives it, and why it matters for organizational performance. J. Organ. Behav. 39, 462-480. doi: 10.1002/job.2244

Seibert, S. E., Silver, S. R., and Randolph, W. A. (2004). Taking empowerment to the next level: a multiple-level model of empowerment, performance, and satisfaction. Acad. Manag. Ann. 47, 332-349. doi: 10.5465/20159585

Shafique, I., and Kalyar, M. (2018). Linking transformational leadership, absorptive capacity, and corporate entrepreneurship. Adm. Sci. 8:9. doi: $10.3390 /$ admsci8020009
Sharon, T. (2020). Blind-sided by privacy? Digital contact tracing, the Apple/Google API and big tech's newfound role as global health policy makers. Ethics Inf. Technol. 1-13. doi: 10.1007/s10676-020-09547-x

Shehata, G. M., Montash, M. A.-H., and Areda, M. R. (2020). Examining the interrelatedness among human resources management practices, entrepreneurial traits and corporate entrepreneurship in emerging markets: an evidence from Egypt. J. Entrep. Emerg. Econ. 13, 353-379. doi: 10.1108/JEEE-08-2019-0117

Si, S., Ahlstrom, D., Wei, J., and Cullen, J. (2020). Business, entrepreneurship and innovation toward poverty reduction. Entrepreneurship Reg. Dev. 32, 1-20. doi: 10.1080/08985626.2019.1640485

Sopiah, S., Kurniawan, D. T., Nora, E., and Narmaditya, B. S. (2020). Does talent management affect employee performance?: the moderating role of work engagement. J. Asian Finance Econ. Bus. 7, 335-341. doi: 10.13106/jafeb.2020.vol7.no7.335

Sparrow, P. R., and Makram, H. (2015). What is the value of talent management? Building value-driven processes within a talent management architecture. Hum. Resour. Manag. Rev. 25, 249-263. doi: 10.1016/j.hrmr.2015.04.002

Srivastava, A., Ramachandran, K., and Suresh, A. (2014). Predictors of employee engagement in R and D organisation. Asia Pac. J. Res. 1, 8-25.

Takata, M., Nakagawa, K., Yoshida, M., Matsuyuki, T., Matsuhashi, T., Kato, K., et al. (2020). Nurturing entrepreneurs: how do technology transfer professionals bridge the valley of death in Japan? Technovation 102161. doi: 10.1016/j.technovation.2020.102161

Tansley, C. (2011). What do we mean by the term "talent" in talent management? Ind. Commer. Train. 43, 266-274. doi: 10.1108/001978511111 45853

Thompson, N. A., Verduijn, K., and Gartner, W. B. (2020). Entrepreneurship-aspractice: grounding contemporary theories of practice into entrepreneurship studies. Entrepreneurship Reg. Dev. 32, 247-256. doi: 10.4324/9781003194002

Trabucchi, D., Bellis, P., Di Marco, D., Buganza, T., and Verganti, R. (2020). Attitude vs. involvement: a systematic literature review at the intersection between engagement and innovation. Eur. J. Innov. Manag. doi: 10.1108/EJIM-05-2020-0171. [Epub ahead of print].

ur Rahman, S. (2019). Manufacturing sector in Pakistan: a comprehensive review for the future growth and development. Pak. J. Humanit. Soc. Sci. 7, 77-91. doi: 10.52131/pjhss.2019.0701.0073

van den Broek, J., Boselie, P., and Paauwe, J. (2018). Cooperative innovation through a talent management pool: a qualitative study on coopetition in healthcare. Eur. Manag. J. 36, 135-144. doi: 10.1016/j.emj.2017.03.012

Vanacker, T. R., Zahra, S. A., and Holmes, R. M. (2017). Corporate entrepreneurship, firm performance, and institutions: evidence from european firms. Acad. Manag. Proc. 2017:15764. doi: 10.5465/AMBPP.2017.15764abstract

Zahra, S. A. (1996). Goverance, ownership, and corporate entrepreneurship: the moderating impact of industry technological opportunities. Acad. Manag. Ann. 39, 1713-1735. doi: 10.5465/257076

Zhang, Z., Wan, D., and Jia, M. (2008). Do high-performance human resource practices help corporate entrepreneurship? The mediating role of organizational citizenship behavior. J. High Technol. Manag. Res. 19, 128-138. doi: 10.1016/j.hitech.2008.10.005

Conflict of Interest: The authors declare that the research was conducted in the absence of any commercial or financial relationships that could be construed as a potential conflict of interest.

Publisher's Note: All claims expressed in this article are solely those of the authors and do not necessarily represent those of their affiliated organizations, or those of the publisher, the editors and the reviewers. Any product that may be evaluated in this article, or claim that may be made by its manufacturer, is not guaranteed or endorsed by the publisher.

Copyright (c) 2021 Khan, Mubarik and Shahid. This is an open-access article distributed under the terms of the Creative Commons Attribution License (CC BY). The use, distribution or reproduction in other forums is permitted, provided the original author(s) and the copyright owner(s) are credited and that the original publication in this journal is cited, in accordance with accepted academic practice. No use, distribution or reproduction is permitted which does not comply with these terms. 